\title{
Assessment of flower visiting insects diversity as pollinators in two parks, Kolkata, India
}

\author{
Suchisuvra Chowdhury ${ }^{1}$, Subhodeep Sarkar ${ }^{1}$, Abantika Nandy ${ }^{2}$, \\ Soumendra Nath Talapatra ${ }^{2, *}$ \\ ${ }^{1}$ Department of Environmental Science, Asutosh College \\ 92, S. P. Mukherjee Road, Kolkata - 700026, India \\ ${ }^{2}$ Department of Environmental Science, University of Calcutta \\ 51/1 \& 2 Hazra Road, Kolkata - 700019, India \\ *Phone: 91-33-2461-5445 \\ *E-mail address: ecologylive@yahoo.co.in
}

\begin{abstract}
Insects are depends upon autotrophs and they attract by the flowers colour and shape as pollinator. This is a mutual relationship between flowers and insects. The present study aims to determine flower visiting insect diversity as pollinators in two parks as biomonitoring of automobile air pollution exposure, landscape changes and/or human interactions. The study areas were selected as per heavily-populated neighborhoods, nearby office buildings, nearby roads and continuous vehicular movements, human interactions as visitors, where fences and high levels of human disturbance are common. The study was carried out at 2 sampling stations viz (i) Elliot park and (ii) Agri-Horticulture Society. The flower species were selected viz. Helianthus annuus, Petunia sp. and Buganvilia spectabilis planting above mentioned areas because these species are more common among other species. In each flower, diversity of visiting insects were studied by qualitative and quantitative assessment. Indices were Species richness, Index of Dominance, Relative abundance, ShannonWiener Diversity Index and Evenness Index for insects for all selected sites were calculated using the statistical formulae. The present results clearly indicate that the flower visiting insects are very less in numbers on three flowering species and index values were decreased. This study is a preliminary assessment of flower visiting insects diversity but further researches are needed in relation to pollination efficiencies of flower visiting insects and biochemical and genetic damage study of flowers as well as air pollution load by using instruments. It was concluded that three flowering species viz. sunflower, petunia and bougainvillea are very common both the parks but insect visitors are common but present less in number, which may be due to the vehicular pollution and/or human interference and/or landscape changes due to nearby neighborhood blocks, office and residential buildings etc.
\end{abstract}

Keywords: Insect diversity; Pollination effects; Flower visiting insects; Biomonitoring; Diversity index

\section{INTRODUCTION}

Insects are the diverse group of animals that maintains biodiversity on earth. The majority of insects are herbivorous, and the maximum number of species depends on the 
autotrophic plants. This is a fact there is a mutual and beneficial relationship between the insects and the flowering plants. According to Pickett and Cadenasso (2008), studies on green spaces' (e.g. cemeteries, parks, gardens) have important research area within cities to determine urban ecology.

However, study of biotic communities besides office and residential buildings is important because the area, where humans spend most of their time, they interact with nature and where most ecosystem services are likely interacting on a daily basis. According to Turner et al. (2004), biodiversity study has been shown to be inequitably distributed across cities, potentially due to micro level variation in vegetation and other biological resources. Pollination efficiency is an important part for pollinators that help to know mutualism between flowers and insect visitors (Matsuki, 2008).

Many studies have already been conducted in discrete urban habitats (e.g. city parks, meadow remnants, community and private gardens) by many researchers have affirmed the importance of flower resources for flower-feeding insects viz. bees, ants and other arthropods (Cane 2005; Hernandez et al. 2009; Matteson et al., 2012).

But few studies have done across the spectrum of urban habitats, including residential, office, and different types of green spaces, to enable an evaluation of the effects of land use heterogeneity on biotic communities within cities (Hennig and Ghazoul 2011, Sattler et al. 2010, Wojcik 2011a; b) and decrease insect diversity surroundings polluted industries and highways (Docherty et al., 1997; Holopainen, 2004).

The researchers in their studies have identified the proximate and ultimate distribution of both floral resources and flower-visiting insects across a heterogeneous urban landscape. Matteson et al. (2012) have documented the presence of herbaceous flowering plants and flower-visiting insects (e.g. Diptera, Coleoptera, Lepidoptera, Hymenoptera) across a wide range of urban green spaces and residential and office blocks.

The interested portion of the study was in the direct and indirect effects of development intensity and vegetation on floral resources and flower-visiting insects. The studies have already been done on physico-chemical analysis by air pollution in Kolkata (CPCB, 2009; Citizen's Report, 2011) but no one has attempted easy screening of flower visiting insect diversity near roadside two parks as by automobile pollutants exposure, landscape changes and/or human interactions.

The present study aims to know flower visiting insect diversity as pollinators in two parks as biomonitoring of automobile pollutants exposure, landscape changes and/or human interactions.

\section{MATERIALS AND METHODS}

The study areas were selected as per heavily-populated neighborhoods, nearby office buildings, nearby roads and continuous vehicular movements, human interactions as visitors, where fences and high levels of human disturbance are common. The study was carried out at 2 sampling stations viz (i) Elliot park at Jwaharlal Nehuru road, (latitude $=22^{\circ} 32^{\prime} \mathrm{N}$ and longitude $=88^{\circ} 20^{\prime} \mathrm{E}$ ) and (ii) Agri-horticulture Society at Alipore Road (latitude $=22^{\circ} 31^{\prime}$ $\mathrm{N}$ and longitude $=88^{\circ} 19^{\prime} \mathrm{E}$ ).

The direct and indirect influences on flower visiting insects in two urban habitats, qualitative and quantitative assessment was done on specific floral and insect distributions by transects randomly within these two parks and evaluated relationships among variables for insects visiting on the particular flowering species. Because our sampling design involved 
quantifying insects in, it was not possible to consistently collect insects using traditional methods (e.g. bowls and hand-netting). Sampling was done by visual identification, image capture, and specimen collection in this study.

These two sampling stations mainly two parks were selected on the basis of human interference, moderate and heavy traffic density and continuous vehicular movement nearby roads and human visitors interaction as per visualization. The satellite image of the study area is shown in Fig. 1.

The flower species were selected viz. Helianthus annuus, Petunia sp. and Buganvilia $s p$. planting above mentioned areas because these species are more common among other species. Quadrats of $1 \mathrm{sft}$ area of total 10 numbers were laid down. The 10 flowers were showed randomly from individual flowering plant species of above mentioned area. In each flower, diversity of visiting insects were studied by qualitative and quantitative assessment.

Species richness, Index of Dominance, Relative abundance, Shannon-Wiener Diversity Index, and Evenness Index for insects for all selected sites were calculated using the following statistics (Stiling, 1999):

$$
\text { Species Richness }(d)=S-1 / \ln N
$$

where, $\mathrm{S}=$ number of species, $\ln \mathrm{N}=$ natural logarithm of the total number of individuals

$$
\text { Index of Dominance }(C)=\sum(n i / N)^{2}
$$

where, $\mathrm{ni}=$ importance value for each species (number of individuals), $\mathrm{N}=$ total number of importance value

$$
\begin{aligned}
& \text { Relative abundance (Pi) } \\
& \qquad \mathrm{Pi}=\mathrm{Ni} / \mathrm{N}
\end{aligned}
$$

where, $\mathrm{Ni}$ is the number of Individuals of a species, and $\mathrm{N}$ is total population of birds.

$$
\begin{gathered}
\text { Shannon-Wiener diversity index }\left(H^{\prime}\right) \\
\mathrm{H}^{\prime}=-\left[\sum \mathrm{Pi} \ln \mathrm{Pi}\right]
\end{gathered}
$$

where, $\mathrm{Pi}$ is proportion of species $\mathrm{i}$ relative to the total number of species, and $\ln \mathrm{Pi}$ is natural logarithm of this proportion.

\section{Evenness index Species Evenness $=\mathrm{H}^{\prime} / \ln (\mathrm{S})$}

where, $H^{\prime}$ is Shannon Diversity Index; $\mathrm{S}$ is Species Richness (number of species), and ln (S) is natural logarithm of species Richness. 


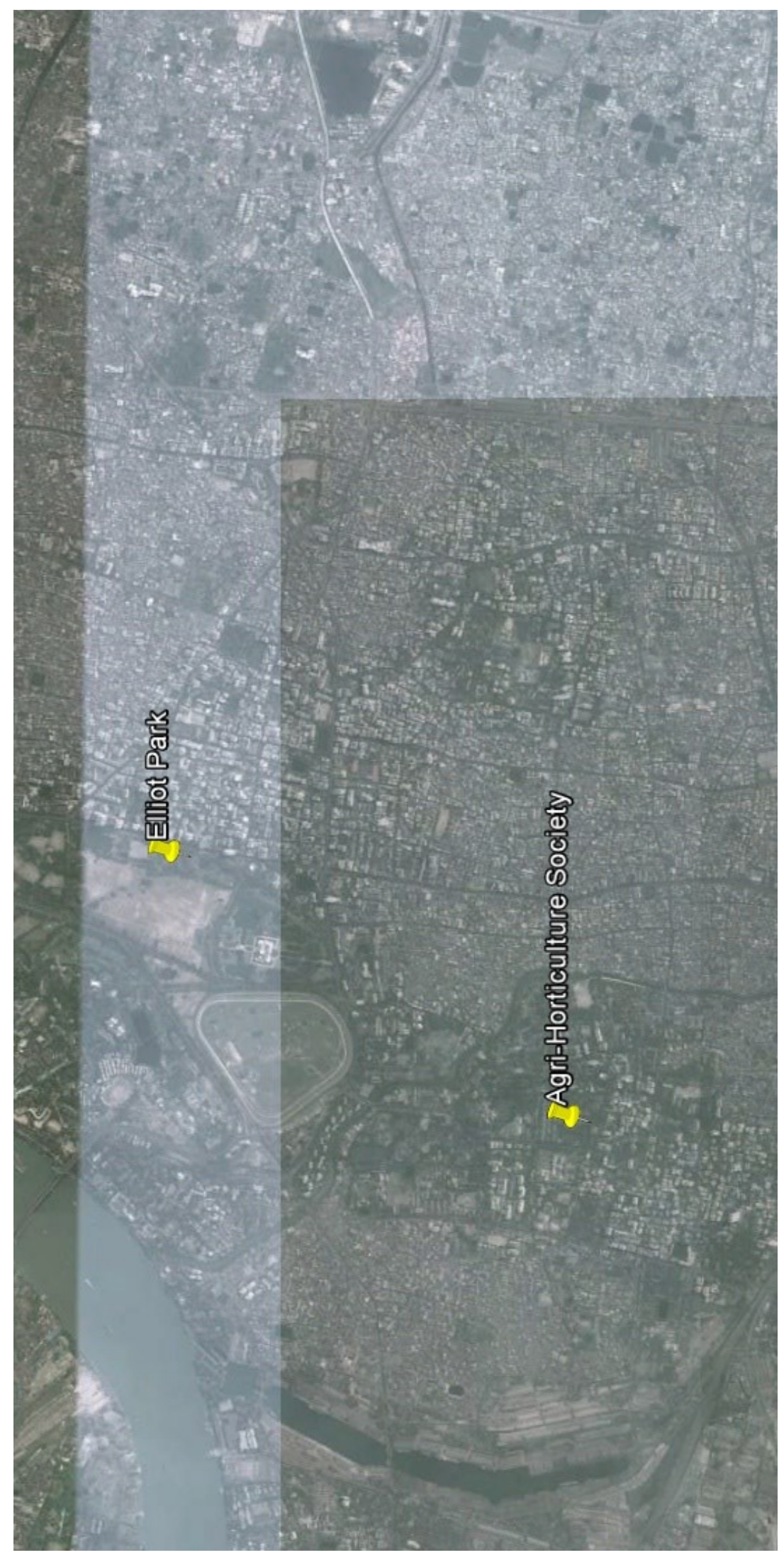

Fig.1. Satellite image of sampling points within study area (Source: Google Earth). 


\section{RESULTS}

The present results clearly indicate that the flower visiting insects are very few in numbers on three flowering species (Table 1).

In Elliot Park, total number of species was observed 31 in sunflower, 09 in petunia and 16 in bougainvillea flowers while in Agri-Horticulture Society 17 in sunflower, 04 in petunia and 06 in bougainvillea flowers were found. The insect species were found honey bee, bumble bee, beetle, dragon fly, small red and black ant, fire ant, butterfly, hoverfly and ladybug beetle in Elliot Park and absence of insects were also observed in one sunflower and five petunia flower while in Agri-Horticulture Society, leaf beetle, large black ant, crab spider, bottle fly, stick insect, evening brown butterfly, grasshopper along with above mentioned few insect species and also observed absence of insect species in petunia (6) and bougainvillea (5) flowers (Table 1).

Table 1. Assessment of flower visiting insects in Elliot Park and Agri-Horticulture Society, Kolkata.

\begin{tabular}{|c|c|c|c|c|c|c|}
\hline Sl. No. & $\begin{array}{c}\text { Flower } \\
\text { species } \\
\text { (Scientific } \\
\text { name) }\end{array}$ & $\begin{array}{l}\text { Flower } \\
\text { colour }\end{array}$ & $\begin{array}{c}\text { Insects } \\
\text { Species in } \\
\text { Eliot park } \\
\text { Common } \\
\text { name, } \\
\text { Scientific } \\
\text { name }\end{array}$ & $\begin{array}{l}\text { No. of } \\
\text { individual } \\
\text { species }\end{array}$ & $\begin{array}{l}\text { Insects Species in } \\
\text { Horticulture Society } \\
\text { Common name, } \\
\text { Scientific name }\end{array}$ & $\begin{array}{c}\text { No. of } \\
\text { individual } \\
\text { species }\end{array}$ \\
\hline 1 & $\begin{array}{c}\text { Sun flower } \\
\text { (Helianthus } \\
\text { annuus) }\end{array}$ & $\begin{array}{c}\text { Yellow } \\
\text { petals and } \\
\text { central } \\
\text { florets are } \\
\text { brown }\end{array}$ & $\begin{array}{l}\text { Honeybee, } \\
\text { Apis sp. }\end{array}$ & 8 & $\begin{array}{l}\text { Leaf beetle, } \\
\text { Phyllotreta } s p \text {. }\end{array}$ & 2 \\
\hline 2 & $\begin{array}{c}\text { Sun flower } \\
\text { (Helianthus } \\
\text { annuus) }\end{array}$ & $\begin{array}{c}\text { Yellow } \\
\text { petals and } \\
\text { central } \\
\text { florets are } \\
\text { brown }\end{array}$ & $\begin{array}{l}\text { Honeybee, } \\
\text { Apis sp. }\end{array}$ & 4 & $\begin{array}{l}\text { Leaf beetle, } \\
\text { Phyllotreta sp. }\end{array}$ & 1 \\
\hline 3 & $\begin{array}{c}\text { Sun flower } \\
\text { (Helianthus } \\
\text { annuus) }\end{array}$ & $\begin{array}{c}\text { Yellow } \\
\text { petals and } \\
\text { central } \\
\text { florets are } \\
\text { brown }\end{array}$ & $\begin{array}{l}\text { Honeybee, } \\
\text { Apis sp. }\end{array}$ & 4 & $\begin{array}{c}\text { Lady bug beetle, } \\
\text { Coccinella } \\
\text { transversalis }\end{array}$ & 2 \\
\hline 4 & $\begin{array}{l}\text { Sun flower } \\
\text { (Helianthus } \\
\text { annuus) }\end{array}$ & $\begin{array}{c}\text { Yellow } \\
\text { petals and } \\
\text { central } \\
\text { florets are } \\
\text { brown }\end{array}$ & $\begin{array}{l}\text { Honeybee, } \\
\text { Apis sp. }\end{array}$ & 3 & $\begin{array}{c}\text { Dragonfly, Ceriagrion } \\
\text { coromandelianum }\end{array}$ & 1 \\
\hline 5 & $\begin{array}{c}\text { Sun flower } \\
\text { (Helianthus } \\
\text { annuus) }\end{array}$ & $\begin{array}{c}\text { Yellow } \\
\text { petals and } \\
\text { central } \\
\text { florets are } \\
\text { brown }\end{array}$ & $\begin{array}{l}\text { Honeybee, } \\
\text { Apis sp. }\end{array}$ & 2 & $\begin{array}{l}\text { Lady bug Beetle, } \\
\text { Harmonia sp. }\end{array}$ & 3 \\
\hline 6 & $\begin{array}{l}\text { Sun flower } \\
\text { (Helianthus }\end{array}$ & $\begin{array}{c}\text { Yellow } \\
\text { petals and }\end{array}$ & $\begin{array}{l}\text { Honeybee, } \\
\text { Apis sp. }\end{array}$ & 3 & Beetle, unidentified & 2 \\
\hline
\end{tabular}




\begin{tabular}{|c|c|c|c|c|c|c|}
\hline & annuus) & $\begin{array}{c}\text { central } \\
\text { florets are } \\
\text { brown } \\
\end{array}$ & & & & \\
\hline 7 & $\begin{array}{l}\text { Sun flower } \\
\text { (Helianthus } \\
\text { annuus) }\end{array}$ & $\begin{array}{l}\text { Yellow } \\
\text { petals and } \\
\text { central } \\
\text { florets are } \\
\text { brown }\end{array}$ & $\begin{array}{l}\text { Honeybee, } \\
\text { Apis sp. }\end{array}$ & 1 & $\begin{array}{l}\text { Hoverfly, } \\
\text { Melanostoma } \\
\text { fasciatum }\end{array}$ & 2 \\
\hline 8 & $\begin{array}{l}\text { Sun flower } \\
\text { (Helianthus } \\
\text { annuus) }\end{array}$ & $\begin{array}{c}\text { Yellow } \\
\text { petals and } \\
\text { central } \\
\text { florets are } \\
\text { brown }\end{array}$ & $\begin{array}{l}\text { Bumble bee, } \\
\text { Bombus sp. }\end{array}$ & 1 & $\begin{array}{l}\text { Large black ant, } \\
\text { Camponotus sp. }\end{array}$ & 2 \\
\hline 9 & $\begin{array}{l}\text { Sun flower } \\
\text { (Helianthus } \\
\text { annuus) }\end{array}$ & $\begin{array}{c}\text { Yellow } \\
\text { petals and } \\
\text { central } \\
\text { florets are } \\
\text { brown }\end{array}$ & $\begin{array}{l}\text { Honeybee, } \\
\text { Apis sp. }\end{array}$ & 5 & $\begin{array}{l}\text { Grass hopper, } \\
\text { Omocestus sp. }\end{array}$ & 1 \\
\hline 10 & $\begin{array}{l}\text { Sun flower } \\
\text { (Helianthus } \\
\text { annuus) }\end{array}$ & $\begin{array}{l}\text { Yellow } \\
\text { petals and } \\
\text { central } \\
\text { florets are } \\
\text { brown }\end{array}$ & $\begin{array}{l}\text { No insects } \\
\text { found }\end{array}$ & 0 & $\begin{array}{l}\text { Dragonfly, } \\
\text { Agriocnemis } s p \text {. }\end{array}$ & 1 \\
\hline 11 & $\begin{array}{l}\text { Petunia flower } \\
\text { (Petunia sp.) }\end{array}$ & Pink petals & $\begin{array}{l}\begin{array}{c}\text { Lady bug } \\
\text { beetle, }\end{array} \\
\text { Coccinella } \\
\text { transversalis } \\
\end{array}$ & 1 & $\begin{array}{l}\text { Common Evening } \\
\text { Brown Butterfly, } \\
\text { Melanitis sp. }\end{array}$ & 1 \\
\hline 12 & $\begin{array}{l}\text { Petunia flower } \\
\text { (Petunia sp.) }\end{array}$ & Pink petals & $\begin{array}{l}\text { Small black } \\
\text { ant, } \\
\text { Monomorium } \\
\text { sp. }\end{array}$ & 1 & $\begin{array}{l}\text { psyche butterfly, } \\
\text { Leptosia sp }\end{array}$ & 1 \\
\hline 13 & $\begin{array}{l}\text { Petunia flower } \\
\text { (Petunia sp.) }\end{array}$ & $\begin{array}{l}\text { Violet } \\
\text { petals and } \\
\text { the edges } \\
\text { are white }\end{array}$ & $\begin{array}{l}\text { Dragonfly, } \\
\text { Agriocnemis } \\
\text { sp. }\end{array}$ & 1 & $\begin{array}{c}\text { Dragonfly,Cceriagrion } \\
\text { coromandelianum }\end{array}$ & 1 \\
\hline 14 & $\begin{array}{l}\text { Petunia flower } \\
\text { (Petunia sp.) }\end{array}$ & Pink petals & $\begin{array}{l}\text { Hoverfly } \\
\text { Melanostoma } \\
\text { fasciatum }\end{array}$ & 1 & $\begin{array}{l}\text { Hoverfly } \\
\text { Melanostoma } \\
\text { fasciatum }\end{array}$ & 1 \\
\hline 15 & $\begin{array}{l}\text { Petunia flower } \\
\text { (Petunia sp.) }\end{array}$ & Pink petals & $\begin{array}{l}\text { Fire ant, } \\
\text { Solenopsis } \\
\text { sp. }\end{array}$ & 5 & No insects found & 0 \\
\hline 16 & $\begin{array}{c}\text { Petunia flower } \\
\text { (Petunia sp.) }\end{array}$ & Pink petals & $\begin{array}{l}\text { No insects } \\
\text { found }\end{array}$ & 0 & No insects found & 0 \\
\hline 17 & $\begin{array}{l}\text { Petunia flower } \\
\text { (Petunia sp.) }\end{array}$ & $\begin{array}{l}\text { Violet } \\
\text { petals and } \\
\text { the edges } \\
\text { are white }\end{array}$ & $\begin{array}{l}\text { No insects } \\
\text { found }\end{array}$ & 0 & $\begin{array}{l}\text { Leaf beetle, } \\
\text { Phyllotreta sp. }\end{array}$ & 0 \\
\hline 18 & $\begin{array}{l}\text { Petunia flower } \\
\text { (Petunia sp.) }\end{array}$ & $\begin{array}{l}\text { Violet } \\
\text { petals and } \\
\text { the edges } \\
\text { are white }\end{array}$ & $\begin{array}{l}\text { No insects } \\
\text { found }\end{array}$ & 0 & $\begin{array}{l}\text { Leaf beetle, } \\
\text { Phyllotreta } s p \text {. }\end{array}$ & 0 \\
\hline
\end{tabular}




\begin{tabular}{|c|c|c|c|c|c|c|}
\hline Sl. No. & $\begin{array}{c}\text { Flower } \\
\text { species } \\
\text { (Scientific } \\
\text { name) }\end{array}$ & $\begin{array}{l}\text { Flower } \\
\text { colour }\end{array}$ & $\begin{array}{c}\text { Insects } \\
\text { Species in } \\
\text { Eliot park } \\
\text { Common } \\
\text { name, } \\
\text { Scientific } \\
\text { name }\end{array}$ & $\begin{array}{c}\text { No. of } \\
\text { individual } \\
\text { species }\end{array}$ & $\begin{array}{l}\text { Insects Species in } \\
\text { Horticulture Society } \\
\text { Common name, } \\
\text { Scientific name }\end{array}$ & $\begin{array}{c}\text { No. of } \\
\text { individual } \\
\text { species }\end{array}$ \\
\hline 19 & $\begin{array}{l}\text { Petunia flower } \\
\text { (Petunia sp.) }\end{array}$ & Pink petals & $\begin{array}{l}\text { No insects } \\
\text { found }\end{array}$ & 0 & No insects found & 0 \\
\hline 20 & $\begin{array}{l}\text { Petunia flower } \\
\text { (Petunia sp.) }\end{array}$ & Pink petals & $\begin{array}{l}\text { No insects } \\
\text { found }\end{array}$ & 0 & No insects found & 0 \\
\hline 21 & $\begin{array}{c}\text { Bougainvillea } \\
\text { (Bougainvillea } \\
\text { spectabilis) }\end{array}$ & Pink petals & $\begin{array}{l}\text { Bumblebee, } \\
\text { Bombus sp. }\end{array}$ & 1 & $\begin{array}{c}\text { Crabspider, } \\
\text { Misumenoides sp. }\end{array}$ & 1 \\
\hline 22 & $\begin{array}{c}\text { Bougainvillea } \\
\text { (Bougainvillea } \\
\text { spectabilis }\end{array}$ & Pink petals & $\begin{array}{c}\text { Psyche } \\
\text { butterfly, } \\
\text { Leptosia sp. }\end{array}$ & 1 & $\begin{array}{c}\text { Blue/Green Bottle Fly } \\
\text { - Calliphora sp. }\end{array}$ & 2 \\
\hline 23 & $\begin{array}{c}\text { Bougainvillea } \\
\text { (Bougainvillea } \\
\text { spectabilis }\end{array}$ & Pink petals & $\begin{array}{l}\text { Hoverfly, } \\
\text { Melanostoma } \\
\text { fasciatum }\end{array}$ & 1 & $\begin{array}{l}\text { Stick insect, } \\
\text { Phasmida sp. }\end{array}$ & 1 \\
\hline 24 & $\begin{array}{c}\text { Bougainvillea } \\
\text { (Bougainvillea } \\
\text { spectabilis }\end{array}$ & Pink petals & $\begin{array}{l}\text { Hoverfly, } \\
\text { Melanostoma } \\
\text { fasciatum }\end{array}$ & 1 & $\begin{array}{l}\text { Green marsh hawk } \\
\text { dragonfly, } \\
\text { Orthetrum sabina }\end{array}$ & 1 \\
\hline 25 & $\begin{array}{c}\text { Bougainvillea } \\
\text { (Bougainvillea } \\
\text { spectabilis }\end{array}$ & Pink petals & $\begin{array}{l}\text { ladybug } \\
\text { bettle, } \\
\text { Harmonia sp. }\end{array}$ & 3 & $\begin{array}{c}\text { Dragon fly, } \\
\text { Ceriagrion } \\
\text { coromandelianum }\end{array}$ & 1 \\
\hline 26 & $\begin{array}{c}\text { Bougainvillea } \\
\text { (Bougainvillea } \\
\text { spectabilis }\end{array}$ & Pink petals & $\begin{array}{l}\text { Hoverfly, } \\
\text { Melanostoma } \\
\text { fasciatum }\end{array}$ & 1 & No insects found & 0 \\
\hline 27 & $\begin{array}{c}\text { Bougainvillea } \\
\text { (Bougainvillea } \\
\text { spectabilis }\end{array}$ & Pink petals & $\begin{array}{l}\text { Hoverfly, } \\
\text { Melanostoma } \\
\text { fasciatum }\end{array}$ & 1 & No insects found & 0 \\
\hline 28 & $\begin{array}{c}\text { Bougainvillea } \\
\text { (Bougainvillea } \\
\text { spectabilis }\end{array}$ & Pink petals & $\begin{array}{l}\text { Large black } \\
\text { ant, } \\
\text { Camponotus } \\
\text { sp. }\end{array}$ & 1 & No insects found & 0 \\
\hline 29 & $\begin{array}{c}\text { Bougainvillea } \\
\text { (Bougainvillea } \\
\text { spectabilis }\end{array}$ & Pink petals & $\begin{array}{c}\text { ladybug } \\
\text { bettle, } \\
\text { Coccinella } \\
\text { transversalis } \\
\end{array}$ & 5 & No insects found & 0 \\
\hline 30 & $\begin{array}{c}\text { Bougainvillea } \\
\text { (Bougainvillea } \\
\text { spectabilis }\end{array}$ & Pink petals & $\begin{array}{l}\text { Hoverfly, } \\
\text { Melanostoma } \\
\text { fasciatum }\end{array}$ & 1 & No insects found & 0 \\
\hline
\end{tabular}


Table 2. Comparison of different indices for flower visiting insects between Elliot park and Agri-Horticulture Society, Kolkata.

\begin{tabular}{|c|c|c|c|c|c|c|c|}
\hline \multirow{2}{*}{ S1. No. } & \multirow{2}{*}{ Different indices } & \multicolumn{3}{|c|}{ Elliot park } & \multicolumn{2}{c|}{ Agri-Horticulture Society } \\
\cline { 3 - 8 } & & Sun flower & Petunia & $\begin{array}{c}\text { Bougain } \\
\text { villea }\end{array}$ & $\begin{array}{c}\text { Sun } \\
\text { flower }\end{array}$ & Petunia & $\begin{array}{c}\text { Bougainv } \\
\text { illea }\end{array}$ \\
\hline 1. & Species richness & 2 & 5 & 5 & 7 & 4 & 5 \\
\hline 2. & Index of dominance & 0.15 & 0.36 & 0.16 & 0.11 & 0.25 & 0.22 \\
\hline 3. & Relative abundance & 1 & 1 & 1 & 1 & 1 & 1 \\
\hline 4. & $\begin{array}{c}\text { Shanon-Weiner } \\
\text { Diversity index }\end{array}$ & 2.02 & 1.30 & 2.06 & 2.23 & 1.39 & 1.56 \\
\hline 5. & Evenness index & 2.92 & 0.81 & 1.28 & 1.15 & 1.00 & 1.00 \\
\hline 6. & Census index & 0.31 & 0.09 & 0.16 & 0.17 & 0.04 & 0.06 \\
\hline
\end{tabular}

It was observed for different diversity indices for flower visiting insects (Table 2), species richness was found high value as 7 and low value as 2 for sunflower in AgriHorticulture society when compared to Elliot park. In case of petunia the values were 5 and 4 in both the area while bougainvillea, all values are same in both the area as 5. For index of dominance value, 0.36 was higher in petunia flower in Elliot park and lower value 0.11 in sunflower in Horticulture society while in petunia and bougainvillea flower values were 0.25 and 0.22 in Agri-Horticulture society and the values were 0.16 and 0.15 in bougainvillea and sunflower in Elliot park. In case of relative abundance all values were same as 1 for both the study area. For Shanon-Weiner diversity index, higher value 2.23 was observed in sunflower in Agri-Horticulture society and lower value 1.30 in petunia flower at Elliot park while in Elliot park the values were 2.06 and 2.02 observed in and sunflower but in Horticulture society the values were 1.56 in bougainvillea and 1.39 in petunia. In case of evenness index, it was observed highest value 2.92 in sunflower and lowest value 0.81 in petunia but 1.28 in bougainvillea at Elliot park while in Agri-Horticulture society the values were 1.15 in sunflower and 1 for both species like petunia and bougainvillea. In case of census index, it was observed highest value 0.31 in sunflower at Elliot park and lowest value 0.04 in petunia at Horticulture society while 0.16 in bougainvillea and 0.09 in petunia at Elliot park but 0.17 in sunflower and 0.06 in bougainvillea at Agri-Horticulture society.

\section{DISCUSSION AND CONCLUSION}

The present study of insect diversity onto three common flowering species viz. sunflower (Helianthus annus), Petunia (Petunia sp.) and Bougainvillea (Bougainvillea spectabilis) planting in two parks, namely Elliot Park and Agri-Horticulture Society indicate that flower visiting insects were few in number. But it was already established a mutual and beneficial relationship between the insects and the flowering plants.

The green spaces' (e.g. cemeteries, parks, gardens) study have showed an important research area within cities to determine urban ecology. 
However, study of biotic communities besides office and residential buildings is important because the area, where humans spend most of their time, they interact with nature and where most ecosystem services are likely interacting on a daily basis (Pickett and Cadenasso 2008). According to Turner et al. (2004), biodiversity study has been shown to be inequitably distributed across cities, potentially due to micro level variation in vegetation and other biological resources.

The adverse impacts of air pollution, human interference and/or landscape change on flower visiting insects with special reference to particular flowering plant species have already been studied nationally and internationally (Cane 2005; Hernandez et al. 2009; Matteson et al., 2012). But few studies have done across the spectrum of urban habitats, including residential, office, and different types of green spaces, to enable an evaluation of the effects of land use heterogeneity on biotic communities within cities (Hennig and Ghazoul, 2011; Sattler et al., 2010; Wojcik, 2011 a; b; Musgrave, 2013) and decrease insect diversity surroundings polluted industries and highways (Docherty et al., 1997). The studies have already been done on physico-chemical analysis by air pollution in Kolkata (CPCB, 2009; Citizen's Report, 2011) but no one has attempted easy screening of flower visiting insect diversity near roadside two parks as by automobile pollutants exposure, landscape changes and/or human interactions.

Generally urban air pollution is a matter of great concern (Li, 2003). This finding supports with evident for other researchers that both the parks are located nearby roads and air pollution may cause impact on flowering plants and the insect visitors were found less in number (Berenbaum, 1995).

According to Matteson et al. (2012), the land cover and its resultant effects on floral resources and flower-visiting insects greatly varied between green spaces and neighborhood blocks. Considering that many common garden flowers are exotic and/or horticultural cultivars that may provide relatively little pollen and/or nectar (Comba et al. 1999), this result has similar observation. Also, in support of this, several flower cultivars that are common in neighborhood blocks but not green spaces (e.g. Petunia, Impatiens, Hydrangea, Rosa, Viola, Lilium) were relatively unattractive to flower-visiting insects. It was observed a variation for different diversity indices for flower visiting insects in both the parks, which is a close similarity with other research works (Cane 2005; Warren et al., 2008; Hernandez et al. 2009; Matteson et al., 2012).

In the present study it was concluded that the less numbers of flower visiting insects and their different diversity indices were found a decreasing trends, which may be the effects of individual and/or combination of air pollutants, human interference, landscape change etc, though there no attempt has been made on physico-chemical properties of present air pollutants. As we know from the previous research work in Indian cities, the concentrations of phytotoxic air pollutants often exceed the toxic limits (Trivedi et al., 2003; CPCB, 2009).

This study is a preliminary assessment of flower visiting insects diversity that have already been studied in greenspace, garden etc. in other parts of globe for aesthetical view of human and biodiversity conservation but further researches are needed in relation to pollination efficiencies of flower visiting insects and biochemical and genetic damage study of flowers as well as air pollution load by using instruments.

It was observed that three flowering species viz. sunflower, petunia and bougainvillea are very common both the parks but insect visitors are common but present less in number, 
which may be due to the vehicular pollution and/or human interference and/or landscape changes due to neighborhood blocks, office and residential buildings etc.

\section{Acknowledgement}

The authors convey their gratitude to the Department of Environmental Science, University of Calcutta, for providing the necessary facilities for doing this study.

\section{References}

[1] Berenbaum M. R., Bugs in the System: Insects and their Impact on Human Affairs (1995) 377 pp., Addision - Weslay.

[2] Blande J. D., Holopainen J. K., Li T., Ecology Letters 13 (2010) 1172-1181.

[3] Cane, J.H., Bees' needs challenged by urbanization. - In: Johnson, E. A. and Klemens, M. W. (eds), Nature in fragments: the legacy of sprawl. Columbia Univ. Press, (2005) pp. 109-124.

[4] Citizen's Report, Centre of Science and Environment (2011) 1-106.

[5] Comba L., Sarah A. Corbet S., Barron A., Bird A., Collinge S. Miyazak N., Powell M., Annals Botany 83 (1999) 369-383.

[6] CPCB, Central Pollution Control Board, New Delhi., (2009). http://www. cpcb. nic.in /bulletin /del/2009html.

[7] Docherty M., Salt D. T., Holopainen J. K., Forests and insects (eds. Watt, A.D., Stork, N.E., Hunter, M.D.) London, Chapman and Hall, (1997) 229-247.

[8] Hennig E. I., Ghazoul J., Perspectives in Plant Ecology, Evolution and Systematics 13 (2011) 137-150.

[9] Hernandez J. L., et al., Cities Environ, http://digitalcommons.lmu.edu/cgi/viewcontent cgi article 1036 (2009).

[10] Holopainen J., Plant - Insect interactions and Pollution, Physiology and Maintenance, Vol. V, Encyclopedia of Life Support Systems (EOLSS).

[11] Li M. H., Arch Environ Contam Toxicol. 45 (2003) 168-176.

[12] Matsuki Y., Tateno R., Shibata M., Isagi Y., Am J Bot 95(8) (2008) 925-930.

[13] Matteson K. C., Grace J. B., Minor E. S., Oikos 2012 01-13.

[14] Musgrave E., Master's Thesis, San Jose State University, htp://scholarworks.sjsu. edu/ etd_theses (2013) 1-95.

[15] Pickett S. T. A., Cadenasso M. L., Journal of Ecology 96 (2008) 8-12.

[16] Sattler S. E., Funnell-Harris D. L., Pedersen J. F., Food Chem. 58 (2010) 3611-3616.

[17] Stiling P. D., Ecology: Theories and applications (3rd edition), 1999.

[18] Trivedi S., Agrawal M., Rajput M., Indian J Air Poll Cont 3 (2003) 44-53.

[19] Turner, W. R. et al., Bioscience 54 (2004) 585-590.

[20] Warren, P. S. et al., Biol. Conserv. 141 (2008) 3-4. 
[21] Wojcik V. A., Journal of Pollination Ecology 4(7) (2011) 48-56.

[22] Wojcik V. A., Journal of the Kansas Entomological Society 84(3) (2011) 197-208.

[23] Yuan J. S., Himanen S., Holopainen J. K., Chen F., Stewart C. N. Jr., Trends in Ecology and Evolution 24 (2011) 323-331.

( Received 04 May 2014; accepted 11 May 2014 ) 